\title{
LAW APPLICABLE TO LIABILITY FOR DAMAGES DUE TO TRAFFIC ACCIDENTS INVOLVING AUTONOMOUS VEHICLES
}

\author{
by \\ MAREK SWIERCZYNSKI", ŁUKASZ ŻARNOWIEC ${ }^{* *}$
}

The authors examine the problem of the law applicable to liability for damages due to traffic accidents involving autonomous vehicles. Existing conflict-of-laws regulation adopted in the Rome II Regulation and both Hague Conventions of 1971 and 1973 is criticized. Upon examination of these legal instruments, it becomes clear that existing regulation is very complex and complicated. In effect authors recommend revisions to the legal framework. Proposed solutions are balanced and take into consideration both the interests of the injured persons, as well the persons claimed to be liable. New approach allows for more individual consideration of specific cases and direct to better outcome of the disputes. The findings may be useful in handling the cases related to use of algorithms of artificial intelligence in private international law.

\section{KEY WORDS}

Algorithms of Artificial Intelligence, Autonomous Vehicles, Conflict-of-laws Rules, Private International Law, Road Accidents, The Conflict of Laws

\section{INTRODUCTION}

Implementation of artificial intelligence algorithms into transport has a direct impact on the civil liability regime. High mobility of autonomous vehicles, different places of manufacturing, purchase and injury due

m.swierczynski@uksw.edu.pl, Professor of Law at the Department of Civil Law and Private International Law of the Faculty of Law and Administration of the Cardinal Stefan Wyszyński University in Warsaw, Poland.

* 1.zarnowiec@uksw.edu.pl, Professor of Law at the Department of Civil Law and Private International Law of the Faculty of Law and Administration of the Cardinal Stefan Wyszyński University in Warsaw, Poland. 
to traffic accidents means that complex transnational torts scenarios are more probable. It is expected that autonomous vehicles will increase road safety. ${ }^{1}$ Currently, approx. $90 \%$ of traffic accidents are caused by human errors. ${ }^{2}$ However, road accidents are unavoidable. Moreover, artificial intelligence algorithms controlling autonomous vehicles have to "make decisions" about the life and health of traffic participants in critical moments. The decision process can take place with or without the human intervention. ${ }^{3}$ The degree of vehicles autonomy may vary. There are vehicles allowing the driver to take control of the car or equipped with artificial intelligence systems that only assist the driver. ${ }^{4}$

In order to determine who is liable for damages, it is necessary to take into account the technology used, including the degree of autonomy of the implemented algorithm and its impact on the occurrence of the traffic accident. $^{5} \quad$ The allocation of liability depends on the circumstances of the individual case. It may involve the liability of the driver, the owner of the vehicle, but also of the manufacturer, parts manufacturer, importer, distributor, vehicle seller, software developer, transport provider or internet service provider. $^{6} \quad$ Uncertainty exists as regards the allocation of responsibilities between different economic operators. Each case must be settled under applicable, national legal system (the applicable law). Depending on the person claimed to be liable the governing law is to be determined on the basis of different conflict-of-laws rules. Court may need

1 Michałowska, M. and Ogłoziński, M. (2017) Smart Solutions in Today's Transport: 17th International Conference on Transport Systems Telematics, TST 2017, Katowice - Ustroń, Poland, April 5-8, 2017, pp. 191-202.

2 Data based on the European Commission's report 'Saving lives: making cars safer in the EU' (COM(2016) 0787 final).

3 Cassart, A. (2017) Aéronefs sans pilote, voitures sans conducteur: la destination plus importante que le voyage. In: H. Jacquemin, A. De Streel (eds.). L'intelligence artificielle et le droit. Bruxelles, p. 319. As for the scope of decision autonomy of artificial intelligence, cf. Nevejans, N. (2017) Traité de droit et d'éthique de la robotique civile. Bordeaux, pp. 134-137.

4 Stone, P. et al. (2016) Artificial Intelligence and Life in 2030. One Hundred Year Study on Artificial Intelligence: Report of the 2015-2016 Study Panel, Stanford University, September 2016. [online] Available from: https://ai100.stanford.edu/sites/default/files/ai100report10032 016fnl_singlep.pdf, p. 19 [Accessed 15 March 2020]. AI technologies may present new safety risks for users when they are embedded in products and services. For example, as result of a flaw in the object recognition technology, an autonomous car can wrongly identify an object on the road and cause an accident involving injuries and material damage [White paper on Artificial Intelligence - A European approach to excellence and trust, Brussels, 19.2.2020 COM(2020) 65 final (hereinafter referred to as „White Paper AI”), p. 12].

5 Gurney, J. (2013) Sue my car not me: Products liability and accidents involving autonomous vehicles. University of Illinois Journal of Law, Technology and Policy, 2, pp. 247-277; Marchand, G. and Lindor, R. (2012) The coming collision between autonomous vehicles and the liability system. Santa Clara Law Review, 52, pp. 1321-1340.

6 Gurney, J. (2013) Op. cit., pp. 258-266. 
to apply not only the specific rules on traffic accidents but also conflict-of-laws rules on product liability or even general conflict-of-laws rules on torts/delicts.

There is an apparent connection between the general topic of this paper (conflict-of-laws) and the specific topic (autonomous vehicles). The connection is apparent in particular with regard to party autonomy, choice of law and how questions of liability can be solved in the context of autonomous vehicles. These issues are closely related to the different types of autonomous vehicles. As long as algorithms implemented in the vehicles act as simple executors of human will, one should establish a normative attribution to the human being in question. For the cases in which the autonomous vehicles exceed this dependency, no clear answer on the applicable law may be found in the existing conflict-of-laws regulation. The applicability of the current conflict-of-laws regulations needs therefore to be explained, taking into consideration the legislator's intention behind the respective rules.

Currently, determination of the law applicable to traffic accidents is highly problematic. In most European countries the governing law is to be determined on the basis of the Convention on the law applicable to traffic accidents, which dates back to the 1970s. The law of the place of accident is used as the basic connecting factor between the accident and the applicable law. However, there are exceptions to this main rule. An alternative is the applicability of the law of the country of registration of the vehicle. The question arises as to whether, with regard to the accidents involving autonomous vehicles, this solution is satisfactory. The current conflict-of-laws regulation seems to be excessively complex in case of traffic accidents. $^{7}$ That is why, clear and understandable conflict-of-laws rules protecting the injured persons are needed. ${ }^{8}$

In this paper we are going to answer the following research questions. Firstly, whether the existing conflict-of-laws regulation is adapted to the liability arising from the damages due to traffic accidents involving autonomous vehicle. Secondly, in case such rules are relevant, whether the result they produce is satisfactory and, in particular, does their application takes into account the protection of the injured party. Thirdly,

7 Klyta, W. (2015) In: M. Pazdan (ed.). System Prawa Prywatnego. Prawo prywatne międzynarodowe. Warszawa, p. 883.

8 Brożek, B. (2017) The Troublesome 'Person'. In: V. Kurki and T. Pietrzykowski (ed s.). Legal Personhood: Animals, Artificial Intelligence and the Unborn. Cham, pp. 3-13. 
what are the possible solutions and how the existing conflict-of-laws regulation could be changed.

\section{LACK OF FULL HARMONISATION OF THE CONFLICT- -OF-LAWS RULES ON TRAFFIC ACCIDENTS}

The basic legal act in the EU on the applicable law to the non-contractual liability, which is the Regulation (EC) No 864/2007 of the European Parliament and of the Council (Rome II) does not provide complete set of conflict-of-laws rules. Among other exclusions and derogations, the Rome II Regulation provides in its Article 28 that international conventions may prevail and different set of conflict-of-laws rules can be applied by the court of the member state. ${ }^{9}$ This is the case of both the 1971 Hague Convention on the Law Applicable to Traffic Accidents ${ }^{10}$ and the 1973 Hague Convention on Dangerous Product Liability, which contain special conflict-of-laws rules applicable for damages due by traffic accidents involving autonomous vehicles. As we see, Article 28 of the Rome II Regulation allows for the coexistence of different sets of conflict-of-laws rules.

In result, different substantive laws may apply in cases relating to liability for damage caused by traffic accidents involving autonomous vehicles depending on the adjudicating court of a member state. That alone problem calls the need of unification and simplification of the system for determining the law applicable to traffic accidents. Such change would increase legal certainty and reduce the possibility of forum shopping, ${ }^{11}$ which is a strategy of referring a case to a court of a particular country in order to apply a law more favourable to the claimant. ${ }^{12}$ Under the current divergent and non-uniformed rules the proceedings can be costly and time-

\footnotetext{
9 Nagy, C. (2010) The Rome II Regulation and Traffic Accidents: Uniform Conflict Rules with some Room for forum shopping - how so?. Journal of Private International Law (Clunet), 6 (1), p. 93.

10 Graziano, T. (2016) Cross-border Traffic Accidents in the EU - the Potential Impact of Driverless Cars, European Parliament - Directorate-General for Internal Policies of the Union. Brussels.

11 On the risk of forum shopping under the Rome II Regulation due to the existence in some EU Member States of the 1971 and 1973 Hague Conventions, cf. Von Hein, J. (2009) Of Older Siblings and Distant Cousins: The Contribution of the Rome II Regulation to the Communitarisation of Private International Law. Rabels Zeitschrift für ausländisches und internationales Privatrecht, 73, p. 474; Unberath, H. and Cziupka, J. (2011) In: T. Rauscher (ed.). Europäisches Zivilprozess- und Kollisionsrecht EuZPR/EuIPR Kommentar. München, p. 749 .

12 On the definition of forum shopping see: point 96 of the Opinion of advocate general Leger delivered on 8 December 2005 in the case C-539/03 Roche Nederland BV, Roche Diagnostic Systems Inc., NV Roche SA, Hoffmann-La Roche AG, Produits Roche SA, Roche Products Ltd, F. Hoffmann-La Roche AG, Hoffmann-La Roche Wien GmbH, Roche AB v. Frederick Primus, Milton Goldenberg, ECLI:EU:C:2005:749.
} 
-consuming for the injured party claiming damages. The mains questions involve the following issues:

1) how to identify the exact cause of the accident,

2) how to provide evidence of that cause and, consequently, and

3) how to decide against whom to pursue a claim for compensation? Is it the owner of the car or its insurer or the manufacturer of the car or its parts? Or, in case of the algorithms, the defendant should be an internet service provider?

The need for unification and simplification of the conflict-of-laws rules does not require that the injured party must be treated in favoured way. Legal framework of conflict-of-laws rules should be balanced and take into account also the legitimate interests of the person claimed to be liable. This argument is particularly relevant where the likelihood of liability is directly linked to the innovation. Making a producer solely liable for the damages would discourage innovation.

Where the law of another EU member state is designated, the network created by Council Decision 2001/470/EC of 28 May 2001 establishing a European Judicial Network in civil and commercial matters, ${ }^{13}$ plays a part in assisting courts of the member states with regard to the content of foreign law.

\section{THE CONFLICT-OF-LAWS REGULATION OF THE 1971 HAGUE CONVENTION}

Number of European countries are members to the Hague Convention of 4 May 1971 on the law applicable to traffic accidents. ${ }^{14}$ In accordance with the principle of universality, the Convention applies even where

13 OJ L 174, 27.6.2001, p. 25. To guarantee access to appropriate, good-quality information, the Commission regularly updates it in the Internet-based public information system set up by Council Decision 2001/470/EC. See Report from the Commission to the Council, the European Parliament and the European Economic and Social Committee of 16 May 2006 on the application of Council Decision 2001/470/EC establishing a European Judicial Network in civil and commercial matters [COM(2006) 203 final - Not published in the Official Journal]. However, the available information is not always adequate and up to date and the website only contains information about EU legal systems while the Rome II Regulation may require judges to apply the law of a third State.

14 As of 28 December 2018, the Convention is in force in 21 States, i.e. the United States of America and the United States of America: Austria, Belarus, Belgium, Bosnia and Herzegovina, Croatia, The Czech Republic, Macedonia, France, Latvia, Lithuania, Luxembourg, Montenegro, Morocco, The Netherlands, Poland, Serbia, Slovakia, Slovenia, Spain, Switzerland, Ukraine, data available at the website: https://www.hcch.net/en/ instruments/conventions/status-table/?cid=81=81 [Accessed 15 March 2020]. 
the applicable law is not that of the State Party to the Convention, irrespective of whether the condition of conflict of laws reciprocity has been satisfied [Article 11(2)]. In the context of autonomous vehicles, it is important to underline that the Convention does not apply to the liability of manufacturers, dealers and repairers of vehicles [Article 2(1)]. These exclusion should be understood broadly and include manufacturers, sellers and repairers of components. ${ }^{15}$ It is, however, difficult to justify why the Convention should not be applied to car manufacturers and at the same time be applicable to the manufacturers of their parts. Still, on the basis of such exclusion, we are of opinion that it includes components based on algorithms that had been used to control the autonomous functions of the vehicle or used in the cars software.

Traffic accident within the meaning of the Hague Convention means an accident involving one or more power-driven or non-powered vehicles involving traffic on a public road, in an area open to the public or in private property accessible to certain persons (Article 1, Sentence 2). The very concept of accident, although essential for determining the scope of the Convention and for determining the applicable law on the basis of the Convention, is not defined by the provisions of the Convention. It may be understood as a sudden external event involving one or more vehicles and leading to personal injury or damage to property.

In principle, the law applicable to non-contractual civil liability in the event of a road traffic accident is, under the provisions of the Hague Convention, the law of the State in which the accident occurs (Article 3). However, Article 4 of the Convention provides many derogations from this general rule.

Although the Convention does not explicitly address the question of the choice of the law by the parties, such solution (based on the freedom of will of the parties) seems to be accepted by many authors, ${ }^{16}$ and confirmed in the courts. ${ }^{17}$ The law chosen by the parties has priority and

\footnotetext{
Klyta, W. (2015) Op. cit., p. 891.

16 Hoyer, H. (1991) Haager Straßenverkehrsübereinkommen und Rechtswahl der Parteien, Zeitschrift für Rechtsvergleichung, p. 341; Kegel, G. (2000) In: G. Kegel and K. Schurig (eds.). Internationales Privatrecht. München, p. 645; Halfmeier, A. and Sonder, N. (2011) In: G. Calliess (ed.). Rome Regulations: Commentary on the European Rules of the Conflict of Laws. Alphen aan den Rijn, p. 642; Ofner, H. (2011) Die Rom II - Verordnung - Neues Internationales Privatrecht für außervertragliche Schuldverhältnisse in der Europäischen Union. Zeitschrift für Rechtsvergleichung, 1, p. 22.
} 
exclude the application of the conflict-of-laws rules of the Conventions that are based on the objective connecting factors. ${ }^{18}$

\section{COMPARISON OF 1973 HAGUE CONVENTION AND ROME II REGULATION}

Due to the exclusion contained in the Article 2(1) of the Hague Convention of 4 May 1971, conflict-of-laws rules relevant to product liability are of particular importance when it comes to the liability of participants in the production and distribution chain of autonomous vehicles. Approaches for determination of the law applicable to product liability varies between EU Member States. Depending on the adjudicating court, different national law may be regarded as the governing law in the case under the same circumstances. Such negative effects of forum shopping are not fully eliminated by the ongoing unification of substantive law within the EU. The liability for damage caused by product, including autonomous vehicle, has been only partially harmonised under the Directive 85/374/EEC. ${ }^{19}$ Moreover, the Directive does not regulate liability for damage caused by an intangible product (e.g. computer software).

In some member states, ${ }^{20}$ the Hague Convention of 2 October 1973 on the law applicable to product liability is to be applied. The conflict-of-laws regulation adopted in this Convention is very complex. As a result, few States have signed the Convention and even fewer have ratified it. ${ }^{21}$ The conflict-of-laws rules contained therein are not based on a single connecting factor, but on group of connecting factors jointly determining the applicable legal system.

17 OGH, the ruling of 26 January 19952 Ob. 11/94. Available from: https://www.rip.bka.gv.at/ Dokument.wxe?Abfrage=Justiz\&Dokumentnummer=JJT_19950126_OGH0002_0020OB0001 1_9400000_000 [Accessed 15 March 2020].

18 The practical significance of this type of choice in relation to road accidents is explained by Graziano, T. (2016) Op. cit., p. 27 and Von Hein, J. (2009) Op. cit., p. 170.

19 Under the Product Liability Directive, a manufacturer is liable for damage caused by a defective product. However, in the case of an AI based system such as autonomous cars, it may be difficult to prove that there is a defect in the product, the damage that has occurred and the causal link between the two. In addition, there is some uncertainty about how and to what extent the Product Liability Directive applies in the case of certain types of defects, for example if these result from weaknesses in the cybersecurity of the product (see White Paper AI, p. 13).

20 These are Croatia, Finland, France, Luxembourg, The Netherlands, Slovenia, Spain as of 27 December 2018, according to the data available on the website of the Hague Conference on Private International Law - http://www.hcch.net/index_en.php?act=convention p.status\&cid $=84$ [Accessed 15 March 2020].

21 The status of the Convention is available from: https://www.hcch.net/en/instruments/ conventions/status-table/?cid=84 [Accessed 15 March 2020]. 
The Convention does not explicitly address the question of the choice of the law made by the parties. Such solution is nevertheless accepted by some authors. ${ }^{22}$

In the member states that have not acceded to the 1973 Hague Convention, the determination of the law applicable to the assessment of product liability is made on the basis of the Rome II Regulation.

What is important in case of autonomous vehicles is that the conflict-of-law rules system set out in the Rome II Regulation covers not only non-contractual obligations based on principle of guilt but also such arising out of strict liability and that the law applicable also govern the question of the capacity to incur liability in tort (delict).

Primarily, the parties are allowed to choose the applicable law (Article 14). ${ }^{23}$ Rome II Regulation introduced the principle of party autonomy and allows parties to choose applicable law, provided that certain conditions are met. The aim of this solution is to enhance legal certainty. So far courts of the member states' practice shows that the parties (even professional entrepreneurs) rarely apply this solution. Nevertheless, it has many benefits, ${ }^{24}$ such as certainty of the parties that a given law will be the governing law for the dispute, which enables foreseeing the result of the dispute, and that the choice of legi fori (i.e. Czech law if the matter is seized by Czech courts) facilitates and accelerates judicial proceedings.

Article 14 para. 1 point (a) of the Rome II Regulation allows the parties to enter into agreement submitting the non-contractual obligations to the law of their choice, provided that such agreement is entered into after the event giving rise to the damage occurred (so called subsequent choice of law). This condition has its aim at protection of weaker parties (typically the injured ones). ${ }^{25}$ Additionally, Article 14 para. 1 point (b) of the Regulation allows the parties pursuing a commercial activity, to enter

22 Légier, G. (2007) Le réglement Rome II sur la loi applicable aux obligations non contractuelles, JCP/La Semaine Juridique - Edition Générale, 21 November 2007, I-207, pp. 54 and 56; Von Hein, J. (2009) Europäisches Internationales Deliktsrecht nach der Rom II - Verordnung. Zeitschrift für Europäisches Privatrecht, 1, p. 32.

${ }_{23}$ Żarnowiec, Ł. (2009) Prawo właściwe dla odpowiedzialności za szkodę wyrządzoną przez produkt niebezpieczny w świetle przepisów rozporządzenia Rzym II. Problemy Prawa Prywatnego Międzynarodowego, 5, pp. 102-103.

24 Pajor, T. (2002) Comments on a preliminary draft proposal for a Council Regulation on the law applicable to non-contractual obligations, pp. 4 and 12-13; Basedow, J. et al. (2003) Hamburg Group for Private International Law, Comments on the European Commission's Draft Proposal for a Council Regulation on the Law Applicable to Non-Contractual Obligations, Rabels Zeitschrift für ausländisches und internationales Privatrecht, 67, pp. 35-36.

25 Czepelak, M. (2015) Autonomia woli w prawie prywatnym międzynarodowym Unii Europejskiej. Warszawa, p. 62. 
into such agreement even before the event giving rise to the damage occurred, provided that an agreement is freely negotiated (so called prior choice of law). This second option may be useful for entrepreneurs remaining in sustainable economic relations, in particular those already bonded by mutual contractual obligations and further want to enhance their confidence and trust. ${ }^{26}$ The choice may be explicit or implicit, provided that it is expressed or demonstrated with reasonable certainty by the circumstances of the case. Where establishing the existence of the agreement, the court has to respect the intentions of the parties. It may not prejudice the rights of third parties (Article 14 para. 1 sentence 2).

It is beyond doubt that this solution enhances legal certainty particularly in case of new technologies, such as autonomous cars as the entities pursuing commercial activity - by the reasonable choice of law - may exclude the applicability of an unknown foreign law. The above-mentioned rule enables, therefore, the introduction of a specific choice-of-law clause into a contract. Such a clause may cover not only contractual obligations, but also non-contractual obligations, in particular those arising from torts, which may occur between the parties in connection to the execution of the contract (i.e. on the rental of the autonomous vehicle). It enables the uniform application of the chosen law, both with regard to contractual and non-contractual obligations.

Similarly as in case of contractual obligations, where all the elements relevant to the situation at the time when the event giving rise to the damage occurs are located in a country other than the country whose law has been chosen, the choice of the parties shall not prejudice the application of provisions of the law of that other country which cannot be derogated from by agreement (Art. 14 para. 2 of the Rome II Regulation). An example would be national mandatory safety rules on the autonomous vehicles. This means that such "choice of law" is not full in a meaning that its effects in a material indication of a legal regulation of chosen law only and may not exclude applicability of mandatory rules of the law of such other country.

Secondly, Article 5 of the Rome II Regulation provides set of conflict-of-laws rules for the product liability. ${ }^{27}$ Such solution is justified by two reasons. The first is the need to strike a balance between the need for

26 Pazdan, M. (2017) Prawo prywatne międzynarodowe. Warszawa, p. 199. 
adequate protection of victims and the legitimate interest of entities claimed to be liable. ${ }^{28}$ The second reason is the elimination of accidental and surprising conflict-of-laws solutions. ${ }^{29}$

However, the scope of the conflict-of-laws rules contained in Article 5 is not fully clear. Most importantly, it is due to the lack of a definition of a "product". This has led to a discrepancy in the interpretations of these provisions. Some authors propose that the definition of the product from Article 2 of the Product Liability Directive 85/374/EEC should be used. ${ }^{30}$ This means that the "product" is only a physical, movable item. This interpretation leads to the exclusion of non-material products, including any digital content, such as software based on algorithms. However, in view of the objectives of the Regulation as well as the recital 11 of its preamble, it seems more justifiable to give the concept of a "product" an autonomous meaning. ${ }^{31}$ This approach make it possible to avoid unnecessary restriction and, consequently, allow to include all kinds of tangible and intangible, movable and immovable products capable of being traded, ${ }^{32}$ including digital content and algorithms.

Nor does it seem appropriate to limit the scope of the conflict-of-laws rules of Article 5 of the Regulation to liability solely for damage caused by the defective product. ${ }^{33}$ These rules specifically do not use the term of "the defective" product. ${ }^{34}$ They refer to damage caused by a product which

27 The creation of numerous exceptions to the general rule determining the law applicable to tort/delict obligations has been criticised in the literature - see Koziol, H. and Thiede, T. (2007) Kritische Bemerkungen zum derzeitigen Stand des Entwurfs einer Rom II Verordnung. Zeitschrift für vergleichende Rechtswissenschaft, 106, pp. 235-247. Concerning the history of the work on this legal norm Heiderhoff, B. (2005) Eine europäische Kollisionsnorm für die Produkthaftung: Gedanken zur Rom II - Verordnung. Zeitschrift für das Privatrecht der Europäischen Union, 2, pp. 92-97.

28 Basedow, J. et al. (2003) Op. cit., p. 15.

29 Żarnowiec, Ł. (2009) Op. cit., p. 776.

30 Stone, P. (2007) The Rome II Regulation On Choice Of Law In Tort. Ankara Law Review, 2, p. 118; Stone, P. (2009) Product Liability under the Rome II Regulation. In: J. Ahern, W. Binchy (eds.). The Rome II, p. 181; Huber, P. and Illmer, M. (2007) International Product Liability. A Commentary on Article 5 of The Rome II Regulation. Yearbook of Private International Law, 9, pp. 37-38; Von Hein, J. (2009) Op. cit., p. 26.

31 Jagielska, M. (2005) Prawo właściwe dla odpowiedzialności za produkt - rozważania na tle projektu rozporządzenia WE o prawie właściwym dla zobowiązań pozaumownych. In: L. Ogiegło, W. Popiołek, M. Szpunar (eds.). Rozprawy prawnicze. Księga pamiątkowa Profesora Maksymiliana Pazdana, Kraków, p. 119.

32 Plender, R. and Wilderspin, M. (2009) The European Private International Law. Oxford, p. 551.

33 Illmer, M. (2009) The New European Private International Law of Product Liability Steering Through Troubled Waters. Rabels Zeitschrift für ausländisches und internationales Privatrecht, 73, pp. 281-282.

34 Dickinson, A. (2008) The Rome II Regulation: The law applicable to non-contractual obligations. Oxford, p. 370. 
is not so much defective as dangerous, and that danger may be a natural characteristic of the category of product concerned, such as autonomous vehicle or its part, and not necessarily a result of its defect.

The conflict-of-laws rule expressed in Article 5 takes into account, on the one hand, the demand to protect the legitimate expectations of the injured party and, on the other hand, protects the interests of the liable entity (e.g. producer of autonomous vehicle). ${ }^{35}$ The law that has priority is the law of habitual residence of the injured party at the time of the occurrence of the damage. This is the legal system of the country in which his personal interests are concentrated and with which the injured party is best acquainted. However, in the case of any of the solutions provided for in Article 5(1)(1)(a) to (c), the interests of the potentially liable party are also adequately protected.

In addition, an escape rule based on a much closer link provided by Article 5(2) may also apply. In practice, it is the case where special relationship between the party held liable and the first purchaser of the product exists. However, any automatism in application of such escape rule by the court should be avoided, and must be always based on an in-depth assessment of the circumstances of the individual accident. ${ }^{36}$

The Rome II Regulation is to applied by courts of the member states in universal way, which means that law determined as applicable under the Regulation must be applied whether or not it is the law of any EU member state. Also application of renvoi is excluded by Article 24 of Rome II Regulation. Such approach significantly decreases forum shopping risk. ${ }^{37}$ Additionally, the Rome II Regulation, must be also applied irrespective of the nature of the court or tribunal seised. This means, among others, that criminal courts of the member states adjudicating non-contractual liability aspects related to crimes are obliged to determine applicable law on the basis of this Regulation.

\section{RECOMMENDATIONS}

As it follows from the above analysis existing conflict-of-laws regulation for the determination of the law applicable to the damages caused by traffic

35 Comp. Hibbert, M. (2007) New EU choice of law rules for tort and product liability claims finalised. European Product Liability Review, 9, pp. 12-14.

36 Żarnowiec, Ł. (2009) Op. cit., p. 784.

37 Pazdan, M. (2017) Op. cit., p. 747. 
accident involving an autonomous vehicle is complicated and complex. It creates a risk of forum shopping and, in addition, makes the legal situation of the injured party more difficult. We therefore recommend change of the conflict-of-laws regulation for accidents involving autonomous vehicles in order to harmonise and simplify the procedure for determination of the applicable law. Injured parties need to enjoy the same level of protection as persons having suffered harm caused by other technologies. At the same time technological innovation should be allowed to continue to develop. ${ }^{38}$

One of the possible solutions is to introduce additional conflict-of-laws rules on traffic accidents into the Rome II Regulation that will be based on the 1971 Hague Convention (this would mean assimilation of the Convention into a Regulation). In result the uniform method of determining the applicable law in all the member states participating in the Regulation could be applied by the courts of the member states, irrespective of whether or not the court state is party to the Hague Convention. Such solution partially eliminates the risk of forum shopping, leading to the application of the same law regardless of the location of the adjudicating court. At the same time, this means that practical problems encountered in the application of the Hague Convention would be mirrored in the Rome II Regulation. That is why this solution is not optimal and should not be recommended. ${ }^{39}$

The issue of road accidents involving autonomous vehicles does not, in our opinion, justify a fundamental change of the method of the applicable law determination, such as applying the new method based on favouring the injured party. ${ }^{40}$ An example would be to split the tort statute (the applicable law) in such a way that the issues of the type of damage covered and the method of calculating compensation are governed by the law of the country of the injured party habitual residence. ${ }^{41}$ This solution is not acceptable. ${ }^{42}$ The person claimed to be liable should not be forced to take into account the potential application of different foreign

\footnotetext{
38 White Paper AI, p. 15.

39 Pazdan, M. et al. (2013) W odpowiedzi na ankietę skierowaną do państw członkowskich Unii, dotyczącą stosowania Rozporządzenia nr 864/2007 o prawie właściwym dla zobowiązań pozaumownych (Rzym II). Problemy Prawa Prywatnego Międzynarodowego, 12, p. 171.

40 As in the case of the weaker party, e.g. consumers in private international law cf. Jacquemin, H. and Hubin, J.-B. (2017) Aspects contractuels et de responsabilité civile en matière d'intelligence artificielle. Bruxelles, pp. 89-93.
} 
laws. ${ }^{43}$ In the case of autonomous vehicles, this argument becomes even more relevant as the person responsible for the damage does not necessarily have to be the vehicle driver.

It is therefore justified to preserve the general application of the law of the place where the direct damage occurred (the place of the accident). This constitutes a compromise for both the person to be liable and the injured party, who cannot count on application of the law of the country of his or her habitual residence. ${ }^{44}$ In addition, it results in application of the same law to assess the liability of different entities potentially liable for the accident involving autonomous car, irrespective of their qualification as a driver, the owner of the vehicle, the transport provider or internet service provider. In the case of the multiple liability of several persons this would be a significant facilitation not only for the injured party, but also in the event of recourse claim between co-debtors.

The question is how to implement this legal framework to existing legislation. In our view, the general provisions of the Rome II Regulation and in particular its Article 4, should be used as the main legal basis. One should agree that the 1971 Hague Convention is an act of inferior quality to the Rome II Regulation. ${ }^{45}$ It's outdated and complicated. It unjustifiably recognises the importance of the place of registration of a vehicle, which is a substitute for the habitual residence of the driver, owner or driver of the vehicle, thereby protecting only the interests of the driver, owner or driver of the vehicle and their insurer. There is no justification for subjecting the type of damage and its assessment to the law favourable to the person claimed to be liable. The priority in all the member states should be given to the provisions of the Rome II Regulation over those of the Convention, at least for those cases when both the injured party and

${ }^{41}$ Such a solution was proposed at the first reading of the draft Rome II regulation in the Parliament, but due to opposition from the Commission and the Council it was not included in the finally adopted text - Symonides. P. (2008) Rome II and Tort Conflicts: A Missed Opportunity. American Journal of Comparative Law, p. 205; Von Hein, J. (2009) Op. cit., pp. 155 and 160.

42 Critical of such a solution: Unberath, H. and Cziupka, J. (2011) In: T. Rauscher (ed.). Europäisches Zivilprozess- und Kollisionsrecht EuZPR/EuIPR Kommentar. München, p. 741.

43 Pazdan, M. et al. (2011) Op. cit., p. 171.

44 Ibid.

45 Staudinger, A. and Czaplinski, P. (2009) Verkehrsopferschutz im Lichte der Rom I-, Rom IIsowie Brüssel I-Verordnung. Neue Juristische Wochenschrift, 3, p. 2254. 
the person held liable were, at the time of the accident, habitually resident in any of the member states. ${ }^{46}$

For both legal instruments, that is the Regulation and the Convention, the basic rule is practically the same, which means that the method for determining the applicable law would remain the same. Under the 1971 Hague Convention (Article 3) the law of the place of the accident is applicable. According to the Rome II Regulation, the governing law is the law of the place of direct damage [Article $4(1)] \cdot{ }^{47}$ For both these legal instruments, the ex-post choice of law is allowed (although such solution is not explicitly provided by the wording of the Convention). ${ }^{48}$ It is worth recalling that the conflict-of-laws rules of the Rome II Regulation are also applicable in matters excluded from the scope of the 1971 Hague Convention.

The main difference would concern the situation when the injured party and the person claimed to be liable have their habitual residence in the same member state. In such case, the Rome II Regulation leads to the application of the law of the country of habitual residence of the parties to the dispute [Article 4(2)]. ${ }^{49}$ This is a significant advantage of the Rome II Regulation over the 1971 Hague Convention. ${ }^{50}$ Furthermore, the Rome II Regulation allows the courts to use, where appropriate, the escape rule [Article 4(3)], without giving any significance to the connecting factor of the place of registration of the vehicle. ${ }^{51}$

Our recommended solution is therefore to give priority to the Rome II Regulation over the 1971 Hague Convention. This requires a corresponding revision to the wording of Article 28 of the Regulation. ${ }^{52}$ One must state that it is disappointing that the opportunity offered by the review clause in Article 30 of the Regulation has not been used for this purpose so far. ${ }^{53}$

${ }^{46}$ Graziano, T. (2016) Op. cit., p. 31; Pazdan, M. et al. (2011) Op. cit., p. 171.

47 As for the practical convergence resulting from the use of both connecting factors, cf. Nagy, C. (2010) Op. cit., pp. 98-99 and 102.

${ }^{48}$ On the benefits, cf. Mills, A. (2018) Party Autonomy in Private International Law. Oxford, pp. 390-454.

49 As regards the practical relevance of this standard in relation to road traffic accidents, see Junker, A. (2008) Das internationale Privatrecht der Straßenverkehrsunfälle nach der Rom II - Verordnung, JuristenZeitung, 4, p. 174.

50 Graziano, T. (2016) Op. cit., p. 27; Graziano, T. (2016) Op. cit., p. 55; Nagy, C. (2010) Op. cit., p. 107.

51 Nagy, C. (2010) Op. cit., p. 107.

52 Halfmeier, A. and Sonder, N. (2011) Op. cit., pp. 642-643; Nagy, C. (2010) Op. cit., p. 108.

${ }^{53}$ Dickinson, A. (2008) Op. cit., p. 362; Staudinger, A. and Czaplinski, P. (2009) Op. cit., p. 2254. 
The following arguments can be used as the justification for such changes in correlation with the review clause in Article 30 of the Regulation. Firstly, a connection with the country where the direct damage occurred (lex loci damni) adopted under Article 4(1) the Rome II Regulation strikes a fair balance between the interests of the person claimed to be liable and the person sustaining the damage, and also reflects the modern approach to civil liability and the development of systems of strict liability. ${ }^{54}$ The main argument is that, while the party claimed to be liable should be protected, the interests of the country where the damage occurred should also be taken into account. It is also justified by the expectations of the injured party. As for the perpetrator, it is argued that he should foresee the place of the result (damage) of his activities. It is also important that the place of damage can be determined with some ease. In recent Florin Lazar judgment rendered on 10 December 2015 (C-350/14), the ECJ observed that the uniform conflict-of-laws rules laid down in the Rome II Regulation purports to "enhance the foreseeability of court decisions" and to

"ensure a reasonable balance between the interests of the person claimed to be liable and the person who has sustained damage",

and that

"a connection with the country where the direct damage occurred [...] strikes a fair balance between the interests of the person claimed to be liable and the person sustaining the damage".

In case of physical injuries caused to a person or the damage caused to goods, the country of the place where the direct damage occurs is the country of the place where the injuries were suffered or the goods were damaged. In the case of a road traffic accident, the damage is constituted by the injuries suffered by the direct victim, while the damage sustained by the close relatives of the latter must be regarded as indirect consequences of the accident. The ECJ clarified the interpretation of Article 4 para. 1 in Florin Lazar judgment with regard to difference between "direct damage" and an "indirect consequence" of the event, which has no bearing on the identification of the applicable law.

54 Świerczyński, M. and Żarnowiec, Ł. (2015) In: Pazdan, M. (ed.). System Prawa Prywatnego. Prawo prywatne międzynarodowe. Warszawa, p. 766. 
In some circumstances exclusive application of lex loci damni rule under Article 4 (1) would lead to excessive simplification of the process of determination of the applicable law, as it is possible that the "gravity" of a non-contractual obligation is located in a different country than the country in which the direct damage occurred. This is why Article 4 in next two paragraphs establishes two major exemptions from this the lex loci rule, making it less arbitrary, and the whole system more workable. Main exception to the principal rule is provided by Article 4 (2) of the Rome II Regulation. It states that where the person claimed to be liable and the person sustaining damage both have their habitual residence in the same country at the time when the damage occurs, the law of that country shall apply. This so called "common law of the parties" reflects the legitimate expectations of the two parties. Under Rome II Regulation courts of the member states should first enquiry whether the person claimed to be liable and the person sustaining damage both had their habitual residence in the same country at the time when the damage occurred, and only if the answer is negative apply law of country in which the direct damage occurred. In both cases the result of law determination can be still changed if the requirements of the "escape clause" are met. ${ }^{55}$

Additionally, an "escape clause" from both Article 4 (1) and (2) is provided by Article 4 para. 3 which allows a departure from both above rules. However, it must be clear from all the circumstances of the case that the tort/delict is manifestly more closely connected with a country other than that indicated in paragraphs 1 or 2, and only is such case, on the basis of this "escape clause" the law of that other country shall apply. There are several limitations preventing courts from excessive, abusive application of this "escape clause", such as requirements that tort/delict connection with such other country must be manifestly more closely connected and that this must be clear from all the circumstances of the case. A useful guideline is provided by the Regulation in the second sentence of Article 4 (3) where it is explained that a manifestly closer connection with another country might be based in particular on a pre-existing relationship between the parties, such as a contract, that is closely connected with the tort/delict in question. The escape clause, in the meaning of art. 4 para. 3, may play an essential role in practice. Courts of the member state are not allowed,

55 Pazdan, M. (2017) Op. cit., p. 199. 
however, to abuse this possibility, by, for example, refusing freedom of choice, or unjustified correction of the conflict-of-laws rules in order to obtain a particular, material aim (i.e. the realisation of the state interest related to the substantive regulation of autonomous vehicles and/or artificial intelligence). It would be incorrect to use Rome II Regulation by court of the member state just to justify application, depending on the case, of legi fori on different basis (e.g. lex loci damni rule or escape clause) whatever suits the judge better. There should be no preference of national law application and discrimination of foreign law.

In our opinion Rome II Regulation does not need to contain any conflict-of-laws rules which directly concern the obligations due to traffic accidents involving autonomous vehicles. The conflict-of-laws framework should be general, synthetic and neutral to face technological development. For this reason, courts of the member states may apply the law of a particular country with a substantial margin of appreciation. However, it does not mean that decision on the applicable law is to be left entirely to the discretion of court, which would be free to determine the national law most closely related to the relevant situation. No doubt, if accepted, such practice would raise the level of legal uncertainty, which might even endanger the safety of transport and use of autonomous vehicles.

The case is different with regard to the potential liability of the manufacturers (importers or sellers) of autonomous vehicles, their components or the digital content (software) on which they operate. In such case, the general public interest in supporting technological development and the call for fair risk-sharing should be taken into consideration. These objectives are fully met by conflict-of-laws rule on product liability laid down in Article 5 of the Rome II Regulation and general rules of its Article 4 does not need to be applied. Although it gives rise to some doubts on interpretation of Article 5, it seems that the adopted conflict-of-laws regulation is well balanced. It strikes a fair balance between the interests and risks of the innovative entrepreneur and users of such innovations, including persons potentially injured by the vehicle.

Another strong argument in favour of the application of Rome II Regulation over the Hague Conventions is that this Regulation also determines the scope of applicable law in some details. Applicable law under the Rome II Regulation covers both the source of an obligation, as well an obligation resulting from an obligation. It applies also to non- 
-contractual obligations that are likely to arise [Article 2 (2)]. Pursuant to Article 15 of the Rome II Regulation the law applicable to non-contractual obligations under the Regulation governs in particular: the basis and extent of liability, including the determination of persons who may be held liable for acts performed by them; the grounds for exemption from liability, any limitation of liability and any division of liability; the existence, the nature and the assessment of damage or the remedy claimed; within the limits of powers conferred on the court by its procedural law, the measures which a court may take to prevent or terminate injury or damage or to ensure the provision of compensation; the question whether a right to claim damages or a remedy may be transferred, including by inheritance; persons entitled to compensation for damage sustained personally; liability for the acts of another person; the manner in which an obligation may be extinguished and rules of prescription and limitation, including rules relating to the commencement, interruption and suspension of a period of prescription or limitation.

The designated law also determines the persons entitled to compensation for damage they have sustained personally. It covers, among others, whether a person other than the "direct victim" may obtain compensation "by ricochet", following damage sustained by the victim. An example is psychological damage, which includes the suffering caused by the death of a close relative, or financial, sustained for example by the children or spouse of a deceased person.

In addition to the general guidelines of Article 15, the Rome II Regulation provides also several useful guidelines relating to the scope of the applicable law. The Regulation applies to non-contractual obligations in civil and commercial matters only, in situations involving a conflict of laws. It does not apply, in particular, to revenue, customs or administrative matters (Art. 1 para. 1). This exclusion needs to be absolutely reasonable as the public and civil law regulations on autonomous vehicles need to be clearly distinguished from one to another. Additionally, pursuant to Article 18 of the Rome II Regulation the person having suffered damage may bring his or her claim directly against the insurer of the person liable to provide compensation if the law applicable to the non-contractual obligation or the law applicable to the insurance contract so provides. This is so called direct action against the insurer of the person liable. 
It is also worth to mention with regard to autonomous vehicles that Article 17 of the Regulation indicates that in assessing the conduct of the person claimed to be liable, account shall be taken, as a matter of fact and in so far as is appropriate, of the rules of safety and conduct which were in force at the place and time of the event giving rise to the liability (rules of safety and conduct). The term "rules of safety and conduct" should be interpreted as referring to all regulations having any relation to safety and conduct, including, for example, road safety rules in the case of an accident (see recital 34 of the Preamble of the Rome II Regulation).

The Rome II Regulation sets out also the framework for refusal of the application of a provision of the law of any country specified by the Regulation due to the public policy (ordre public) of the forum, provided that this exception is permitted only if application of such law is manifestly incompatible with the public policy of the forum (Article 26). For example, the application of a provision of the law designated by the Regulation which would have the effect of causing non-compensatory exemplary or punitive damages of an excessive nature to be awarded to the person injured by the accident involving autonomous vehicles should be treated as being contrary to the public policy (ordre public).

As we see there are many arguments in favour of the uniform application of the Rome II Regulation to all civil consequences resulting from the traffic accident involving autonomous vehicles. However, while endorsing the solution adopted in Article 5 of the Rome II Regulation, it is important to add that the basic objection raised against the EU conflict-of-laws regulation used for determination the law applicable to product liability is the dualism of the sources of law. Some EU member states are still bound by the 1973 Hague Convention. ${ }^{56}$ The critical assessment of the Convention proves that a simple incorporation of its rules into the Rome II Regulation would be wrong. As in the case of the 1971 Hague Convention, a much better and simpler option seems to be to give full priority to the Rome II Regulation over the Convention. As stated above, this also requires revision to the wording of Article 28 of the Rome II Regulation.

56 Pazdan, M. et al. (2013) Op. cit., pp. 177-178. 


\section{CONCLUSIONS}

The following conclusions result from our analysis:

In order to determine who is liable for damages, it is necessary to take into account the technology used, including the degree of autonomy of the concerned vehicle and its impact on the occurrence of the traffic accident. The allocation of liability depends on the circumstances of the individual case.

Uncertainty exists as regards the allocation of responsibilities between different economic operators (e.g. driver, owner of the vehicle, manufacturer or service provider). Each case must be settled under applicable, national legal system (the applicable law). Depending on the person claimed to be liable the governing law is to be determined on the basis of different conflict-of-laws rules.

Court may need to apply not only the specific rules on traffic accidents but also conflict-of-laws rules on product liability (e.g. of the manufacturer of parts) or even general conflict-of-laws rules on torts/delicts.

Currently, determination of the law applicable to traffic accidents is highly problematic. The current conflict-of-laws regulation seems to be excessively complex in case of traffic accidents. This creates a risk of forum shopping and, in addition, makes the legal situation of the injured party more difficult.

The need for unification and simplification of the conflict-of-laws rules does not require that the injured party is to be treated in favoured way. Conflict-of-laws regulation should be balanced and take into account also the legitimate interests of the person claimed to be liable.

In this paper we recommend change of the conflict-of-laws regulation for accidents involving autonomous vehicles in order to harmonise and simplify the procedure for determination of the applicable law. Injured parties need to enjoy the same level of protection as persons having suffered harm caused by other technologies, whilst technological innovation should be allowed to continue to develop.

In this paper we also state that it is reasonable to use as a main basis the general provisions of the Rome II Regulation and in particular its Article 4. Rome II Regulation does not need to be supplemented by any special conflict-of-laws rules which would directly regulate the obligations arising from autonomous vehicles. 
As to the potential liability of the manufacturers (importers or sellers) of autonomous vehicles, their components or the digital content (software) on which they operate, the conflict-of-laws rule on product liability laid down in Article 5 of the Rome II Regulation is satisfactory. It takes into account, on the one hand, the demand to protect the legitimate expectations of the injured party and, on the other hand, protects the interests of the liable entity (e.g. producer of autonomous vehicle).

\section{LIST OF REFERENCES}

[1] Basedow, J. et al. (2003) Hamburg Group for Private International Law, Comments on the European Commission's Draft Proposal for a Council Regulation on the Law Applicable to Non-Contractual Obligations. Rabels Zeitschrift für ausländisches und internationales Privatrecht, 67.

[2] Brożek, B. (2017) The Troublesome 'Person'. In: V. Kurki and T. Pietrzykowski (eds.). Legal Personhood: Animals, Artificial Intelligence and the Unborn. Cham.

[3] Cassart, A. (2017) Aéronefs sans pilote, voitures sans conducteur: la destination plus importante que le voyage. In: H. Jacquemin, A. De Streel (eds.). L'intelligence artificielle et le droit. Bruxelles.

[4] Czepelak, M. (2015) Autonomia woli w prawie prywatnym międzynarodowym Unii Europejskiej. Warszawa.

[5] Dickinson, A. (2008) The Rome II Regulation: The law applicable to non-contractual obligations. Oxford.

[6] European Commission's report 'Saving lives: making cars safer in the EU'. (COM(2016) 0787 final).

[7] Graziano, T. (2016) Cross-border Traffic Accidents in the EU- the Potential Impact of Driverless Cars, European Parliament - Directorate-General for Internal Policies of the Union. Brussels.

[8] Gurney, J. (2013) Sue my car not me: Products liability and accidents involving autonomous vehicles. University of Illinois Journal of Law, Technology and Policy, 2.

[9] Halfmeier, A. and Sonder, N. (2011) In: G. Calliess (ed.). Rome Regulations: Commentary on the European Rules of the Conflict of Laws. Alphen aan den Rijn.

[10] Heiderhoff, B. (2005) Eine europäische Kollisionsnorm für die Produkthaftung: Gedanken zur Rom II - Verordnung. Zeitschrift für das Privatrecht der Europäischen Union, 2. 
[11] Hibbert, M. (2007) New EU choice of law rules for tort and product liability claims finalised. European Product Liability Review, 9.

[12] Hoyer, H. (1991) Haager Straßenverkehrsübereinkommen und Rechtswahl der Parteien. Zeitschrift für Rechtsvergleichung.

[13] Huber, P. and Illmer, M. (2007) International Product Liability. A Commentary on Article 5 of The Rome II Regulation. Yearbook of Private International Law, 9.

[14] Illmer, M. (2009) The New European Private International Law of Product Liability Steering Through Troubled Waters. Rabels Zeitschrift für ausländisches und internationales Privatrecht, 73.

[15] Jacquemin, H. and Hubin, J.-B. (2017) Aspects contractuels et de responsabilité civile en matière d'intelligence artificielle. Bruxelles.

[16] Jagielska, M. (2005) Prawo właściwe dla odpowiedzialności za produkt - rozważania na tle projektu rozporządzenia WE o prawie właściwym dla zobowiązań pozaumownych. In: L. Ogiegło, W. Popiołek, M. Szpunar (eds.). Rozprawy prawnicze. Księga pamiątkowa Profesora Maksymiliana Pazdana, Kraków.

[17] Junker, A. (2008) Das internationale Privatrecht der Straßenverkehrsunfälle nach der Rom II - Verordnung. JuristenZeitung.

[18] Kegel, G. (2000) In: G. Kegel and K. Schurig (eds.). Internationales Privatrecht. München.

[19] Klyta, W. (2015) In: M. Pazdan (ed.). System Prawa Prywatnego. Prawo prywatne międzynarodowe. Warszawa.

[20] Koziol, H. and Thiede, T. (2007) Kritische Bemerkungen zum derzeitigen Stand des Entwurfs einer Rom II - Verordnung. Zeitschrift für vergleichende Rechtswissenschaft, 106.

[21] Légier, G. (2007) Le réglement Rome II sur la loi applicable aux obligations non contractuelles, JCP/ La Semaine Juridique - Edition Générale, 21 November 2007, I-207.

[22] Marchand, G. and Lindor, R. (2012) The coming collision between autonomous vehicles and the liability system. Santa Clara Law Review, 52.

[23] Michałowska, M. and Ogłoziński, M. (2017) Smart Solutions in Today's Transport: 17th International Conference on Transport Systems Telematics, TST 2017, Katowice - Ustroń, Poland, April 5-8, 2017.

[24] Mills, A. (2018) Party Autonomy in Private International Law. Oxford.

[25] Nagy, C. (2010) The Rome II Regulation and Traffic Accidents: Uniform Conflict Rules with some Room for forum shopping - how so?. Journal of Private International Law (Clunet), $6(1)$.

[26] Nevejans, N. (2017) Traité de droit et d'éthique de la robotique civile. Bordeaux. 
[27] Ofner, H. (2011) Die Rom II - Verordnung - Neues Internationales Privatrecht für außervertragliche Schuldverhältnisse in der Europäischen Union. Zeitschrift für Europarecht, Internationales Privatrecht und Rechtsvergleichung, 1.

[28] OGH, the ruling of 26 January 19952 Ob. 11/94. Available from: https://www.rip.bka. gv.at/Dokument.wxe?Abfrage=Justiz\&Dokumentnummer=JJT_19950126_OGH0002_ 0020OB00011_9400000_000 [Accessed 15 March 2020].

[29] Opinion of advocate general Leger delivered on 8 December 2005 in the case C-539/03 Roche Nederland BV, Roche Diagnostic Systems Inc., NV Roche SA, Hoffmann-La Roche AG, Produits Roche SA, Roche Products Ltd, F. Hoffmann-La Roche AG, Hoffmann-La Roche Wien $\mathrm{GmbH}$, Roche AB v. Frederick Primus, Milton Goldenberg, ECLI:EU:C: 2005:749.

[30] Pajor, T. (2002) Comments on a preliminary draft proposal for a Council Regulation on the law applicable to non-contractual obligations.

[31] Pazdan, M. (2017) Prawo prywatne międzynarodowe. Warszawa.

[32] Pazdan, M. et al. (2013) W odpowiedzi na ankietę skierowaną do państw członkowskich Unii, dotyczącą stosowania Rozporządzenia nr 864/2007 o prawie właściwym dla zobowiązań pozaumownych (Rzym II). Problemy Prawa Prywatnego Międzynarodowego, 12.

[33] Plender, R. and Wilderspin, M. (2009) The European Private International Law. Oxford.

[34] Staudinger, A. and Czaplinski, P. (2009) Verkehrsopferschutz im Lichte der Rom I-, Rom II- sowie Brüssel I-Verordnung. Neue Juristische Wochenschrift, 3.

[35] Stone, P. (2007) The Rome II Regulation On Choice Of Law In Tort. Ankara Law Review, 2.

[36] Stone, P. (2009) Product Liability under the Rome II Regulation. In: J. Ahern, W. Binchy (eds.). The Rome II.

[37] Stone, P. et al. (2016) Artificial Intelligence and Life in 2030. One Hundred Year Study on Artificial Intelligence: Report of the 2015-2016 Study Panel, Stanford University, September 2016. [online] Available from: https://ai100.stanford.edu/sites/default/files/ ai100report10032016fnl_singlep.pdf [Accessed 15 March 2020].

[38] Świerczyński, M. and Żarnowiec, Ł. (2015) In: Pazdan, M. (ed.). System Prawa Prywatnego. Prawo prywatne międzynarodowe. Warszawa.

[39] Symonides, P. (2008) Rome II and Tort Conflicts: A Missed Opportunity. American Journal of Comparative Law.

[40] Unberath, H. and Cziupka, J. (2011) In: T. Rauscher (ed.). Europäisches Zivilprozess- und Kollisionsrecht EuZPR/EuIPR Kommentar. München. 
[41] Von Hein, J. (2009) Europäisches Internationales Deliktsrecht nach der Rom II Verordnung. Zeitschrift für Europäisches Privatrecht, 1.

[42] Von Hein, J. (2009) Of Older Siblings and Distant Cousins: The Contribution of the Rome II Regulation to the Communitarisation of Private International Law. Rabels Zeitschrift für ausländisches und internationales Privatrecht, 73.

[43] White paper on Artificial Intelligence - A European approach to excellence and trust, Brussels, 19. 2. 2020 COM(2020) 65 final.

[44] Żarnowiec, Ł. (2009) Prawo właściwe dla odpowiedzialności za szkodę wyrządzoną przez produkt niebezpieczny w świetle przepisów rozporządzenia Rzym II. Problemy Prawa Prywatnego Międzynarodowego, 5. 